\title{
Bağlı Graflarda Etkili Düğümlerin Belirlenmesinde Yeni Bir Yaklaşım
}

\section{A New Approach to Determining Effective Nodes in Linked Graphs}

\author{
Furkan Öztemiz ${ }^{*}\left(\mathbb{0}\right.$, Ali Karcı ${ }^{2}$ \\ 1 İnönü Üniversitesi Mühendislik Fakültesi Bilgisayar Mühendisliği, Malatya, TÜRKIYE \\ 2 İnönü Üniversitesi Mühendislik Fakültesi Yazılım Mühendisliği, Malatya, TÜRKIYE \\ Sorumlu Yazar / Corresponding Author*: furkanoztemiz@gmail.com
}

Geliş Tarihi / Received: 25.12 .2020

Araștırma Makalesi/Research Articl

Kabul Tarihi / Accepted: 20.07.2021

DOI:10.21205/deufmd.2022247014

Atıfșekli/How to cite: ÖZTEMIZ, F, KARCI, A.(2022).Bağlı Graflarda Etkili Düğümlerin Belirlenmesinde Yeni Bir Yaklaşım.DEUFMD, 24(70), 143-155.

Öz

Graf(Çizge) teorisi veri biliminin gelişmesi ile birçok farklı alanda modelleme ve analiz işlemlerinin gerçekleștirilmesinde kullanılmıştır. Farklı türdeki problemlerin çözümlenmesi için çizge teorisinde çok sayıda algoritma ve yöntem geliștirilmiștir. Bu çalıșmada bir çizge yapısı içerisinde bulunan etkili düğümlerin tespit edilmesi amaçlanmıştır. Çizge üzerindeki etkili düğümler sosyal ağlar içerisindeki baskın bireylerin, ulaşım ağları içerisindeki yoğun ve kritik konuma sahip kavşak noktalarının, borsa sistemlerinde birbirini etkileyen firmaların ve seri üretim yapan bir fabrikada otomasyon sisteminin kilit adımlarının tespit edilmesi vb.. birçok farklı alanda çözüm sunmaktadır. Çizgeler üzerindeki etkili düğümlerin tespit edilmesi için çeșitli algoritmalar geliștirilmiștir. Bu çalıșmada yönsüz ve ağırlıksız bir çizgedeki etkili düğümlerin tespit edilmesi için yeni bir algoritma önerilmiştir. Ayrıca mevcut etkili düğüm keșfetme algoritmalarından PageRank, Closeness, Eigenvector, Degree merkezlilik ölçütleri ile karşılaştırılması yapılmıştır. Çalışmada algoritmalara ait sonuçlar dikkate alınarak çizgedeki dügümlerin etkili olma sıralamalarına yer verilmiştir. Algoritmanın kodlanması ve görselleştirme işlemleri için R programlama dili kullanılmıștır.

Anahtar Kelimeler: Merkezlilik ölçütleri, Çizge teorisi, Etkili düğüm, Temel kesme

\section{Abstract}

Graph theory has been used in the development of data science with realization of modeling and analysis processes in many different fields. Numerous algorithms and methods have been developed in graph theory to solve different types of problems. In this study, it is aimed to identify the active nodes in a graph structure. Effective nodes on the graph provide solutions in many different areas such as identifying dominant individuals in social networks, intensive and critical intersections in transportation networks, companies that affect each other in stock market systems, key steps of an automation system in a factory that makes mass production etc.. Various algorithms have been developed for detecting effective-influence nodes on graphs. In this study, a new algorithm is proposed to determine the effective nodes in a non-directional and unweighted graph. Also, comparison with existing effective node discovery algorithms like PageRank, Closeness, Eigenvector, Degree centrality criterion has been made. In the study, taking into consideration the results of the 
algorithms, the influence ranking of the nodes in the graph are given. R programming language is used for coding and visualization of the algorithm.

Keywords: Centrality criterion, Graph theory, Effective node, Fundamental cut-set

\section{Giriş}

Çizgeler önemli temel veri yapılarından birisidir. Hayatın her aşamasında üretilen verilerin bilgisayar sistemlerinde kendine özgü bir biçimde ifade edilme imkânı bulması modelleme ve analiz işlemlerinde önemli avantajlar sağlamaktadır. Gündelik hayattaki problemlere sundukları başarılı çözümler sayesinde çizge teorisi birçok sektörde kendine kullanım alanı bulmuştur. Çizge teorisinde kenar ve dügüm olmak üzere iki temel bileşen vardır [1] Düğümler nesne ve olayları, kenarlar ise bunlar arasındaki bağıntıyı ifade etmekte kullanılır. Bu iki bileşen problemin türüne göre çeşitli modellemelerde kullanılabilir. Örnek olarak beyin deki sinir ağlarının, ulaşım ağı yapısının, sosyal ağlardaki bireylerin bağlantılarının, kimyada moleküllerin yapılarının, sosyolojide sosyal grupların ve bilginin yayılmasının, biyolojide salgının yayılım ağının modellenmesinde kullanılabilir [2]. Her sektörün kendisine özgü problemlerini düşündügümüzde bu sorunlara çözüm aramak için birçok yöntem geliştirilmiştir. Bu çalışmada çizge teorisi temelli geliștirilen yeni bir yöntemden bahsedilmiştir. $\mathrm{Bu}$ yöntem çizge üzerinde etkili olan düğümün(nesnenin) tespit edilmesini amaçlamaktadır. Burada ifade edilen nesne kavramı problemin türüne göre farklı formlara dönüșebilir. Farklı sektörlerdeki birkaç kullanım alanı ile durumu açıklayacak olursak ulaşım ağlarının kesişim noktaları olan kavşak noktalarının yoğunluğunun belirlenmesinde, sosyal ağlar üzerinde bireylerin ve toplulukların temsil ettikleri gücü ve diğer bireyler üzerindeki etkilerinin belirlenmesinde, borsa üzerinde birbirleri arasında bağları bulunan şirketlerin birbirlerini etkileme yani baskı oluşturma durumlarının tespit edilmesinde, Bir üretim merkezindeki otomasyon sistemindeki en etkili cihazın belirlenmesi ile kilit rol oynayan cihazların tespit edilmesinde kullanılabilir $[3,4]$. $\mathrm{Bu}$ çalışmada örnek bir çizge üzerinde önerilen yeni algoritma uygulanmış ve popüler merkezlilik ölçütlerinden pagerank, closeness, eigenvector, degree ölçütleri de aynı çizge üzerinde uygulanarak karşılaștırmalı sonuçlarına yer verilmiștir. Literatürde etkili düğümlerin tespit edilmesine yönelik çalıșmalardan bazıları; Shiva, ağ analizindeki en önemli problemlerden birisi olan dügümlerin önemini belirlemek üzere bir çalışma yapmıștır. Çalıșmasında ağdaki bütün Betweenness Centrality değerlerinin hesaplayabilmek için rastgele paralel bir algoritma ve cebirsel bir yöntem sunmuşlardır. Herhangi bir yol karşılaştırma tabanlı $\mathrm{O}(\mathrm{nm})$ zamanından daha kısa sürede hesaplanamayacağını çalışmalarında göstermiştir [5]. W.Xing ve A. Ghorboni web sayfalarının popülaritesini hesaplamak için geliştirilen pagerank algoritmasını ve ağırlıklı pagerank algoritmasını karşılaştırmışlardır. Pagerank algoritması kendine gelen bağlantı sayısına göre hesaplama yaparken, ağırlıklı pagerank algoritması hem kendine gelen hem de giden bağlantıları hesaba katarak web sitesinin popülerliğini hesaplamaktadır. Yaptıkları çalışma neticesinde ağırlıklı pagerank algoritmasının daha fazla ilgili sayfayı ortaya çıkardığı sonucuna ulaşmışlardır [6]. Z.Yuanyuan wireless sensör ağlarının enerji maliyetini azaltmak için yaptığı çalışmada, sensör ağlarının iletișim yükünü azaltmak için ağ içerisindeki etkili konumdaki sensörleri belirleyerek en az sayıda sensör ile iletişimi gerçekleştirmeyi amaçlamıștır [7]. T.Alahakoon ve arkadaşları çalışmalarında betweenness centrality ile dügüumleri tanımlamak için k-path isminde yeni bir ölçü sistemi geliştirilmesi üzerine çalışmışlardır. Gerçek ve yapay sosyal ağlar üzerinde yapılan deneysel çalışmalarda bilinen başka algoritmalar ile karşılaştırılması yapılmıștır. Bunun sonucunda etkili olan dügümlerin tespit edilmesinde doğruluk değeri ve çalışma süresi açısından kazanç sağladığı görülmüştür [8]. Y.Ding ve arkadaşları pagerank algoritmasını kullanarak sönümleme (damping) faktörlerinin yazarların etkili olma sıralaması üzerine nasıl bir etkisi olduğuna yönelik bir çalışma yapmışlardır. Çalışmalarında 1970 ile 2008 yılları arasında Information retrieval (IR) alanında en çok atıf alan 108 yazara ait veriler kullanılmıștır. 0,05 ile 0,95 arasında değișen sönümleme katsayısı ile pagerank temelli 108 yazarın etkili olma değerleri hesaplanmıștır. Yapılan çalışma neticesinde pagerank sonuçları 
ile atıf dereceleri ve h-indekslerinin etkili olma değerleri üzerinde önemli ölçüde ilişkisi olmadığı sonucuna ulaşmışlardır [9]. V. Jagadishwari ve S. Chakrabarty sosyal ağlarda bağlantı tahmini için closeness centrality yaklaşımlı yeni bir algoritma önermişlerdir. $\mathrm{Bu}$ algoritma online sosyal ağlar üzerinde test edilmiș. Aynı zamanda temel bağlantı tahmin algoritmalarından Common neighbor(CN), Jaccard ve Adamic Adar ile karşılaştırması yapılmıştır. Önerilen algoritmanın temel algoritmalardan daha iyi performans verdiği çalışmada gösterilmiştir [10]. Taras Agryzkov ve arkadașları kentsel ağları için eigenvector centrality yaklaşımına dayanan ağın topolojisine ve ağdan çıkarılan coğrafik referanslı verilerin etkisini ölçen yeni bir centrality modeli önerilmiştir. Yeni modelin belirlenen kentsel ortamdaki perakende ve hizmet kurulușlarının dağılımını ve ilişkilerini ortaya çıkardığ sonuçlarına çalışmalarında yer vermiştir [11].

Literatürde mevcut bulunan bir çok farklı yaklaşıma sahip etkili dügümleri keșfetme algoritmaları(ölçütleri) vardır. Çalışmada yer verdiğimiz merkezlilik ölçütleri incelendiğinde bir düğüme ait etkili olma değerleri hesaplanırken pagerank ölçütü dügüme farklı düğ̈̈mlerden gelen bağlantının kalitesine odaklanmaktadır, closeness ölçütü ilgili düğümün diğer bütün düğümlere en yakın mesafede olması ile ilgilenmektedir, eigenvector ölçütü ilgili düğümün komşu düğümlerinin ne kadar etkili olduğu göz önünde bulundururken, degree ölçütü ilgili düğümün kaç farklı düğüm ile bağlantısı olduğu ile ilgilenmektedir. Kendilerine ait çözüm yaklașımları ile farklı alanlarda bașarı üstünlüklerine sahiptir. Örneğin pagerank daha çok web sayfalarının öneri önceliğinde avantaj sağlarken, closeness ölçütü konumsal alandaki ulaşım sistemlerinde başarılı sonuçlar vermektedir, eigenvector ise sosyal ağlarda etkili yani baskın olan bireylerin belirlenmesinde başarılı sonuçlar üretmektedir. Önerdiğimiz merkezlilik ölçütü literatürdeki mevcut algoritma ve ölçütlerin yaklaşım tarzından uzak özgün bir çözüm yöntemi sunmaktadır. Tasarlanan özel bir dolanım ağacı olan Kmax tree nin düğümleri arasındaki kenar bağıntıları dikkate alınarak çizge üzerinde temel kesme işlemleri uygulanmaktadır. Bu kesme işleminin amacı dügümlere ait kenar bağıntıları kesilerek çizgeyi 2 ayrı kümeye ayırmak ve bu iki küme arasındaki bağıntıların kesilmesi sonrası çizgede etkilenen düğümleri belirlemektir. Hem Kmax tree dolanım ağacı hemde bu ağaç doğrultusunda gerçekleştirilen temel kesme işlemleri daha önce çizgedeki etkili düğümlerin belirlenmesinde literatürde kullanılmamıștır bu durum çalışmayı özgün kılan nedenlerin başında gelmektedir. Örnekler üzerinde önerdiğimiz algoritmanın bütün aşamaları uygulamalı olarak anlatılmıştır.

\section{Materyal ve Metot}

Çizge teorisi öncelikle ağ yapıları gibi karmaşık veri gruplarının modellenmesinde önemli kolaylıklar sağlamaktadır. Tasarlanan ağın analizi, en kısa yolun tespiti gibi popüler problemlerin çözümünde kullanılan önemli bir veri yapısı türüdür. Düğüm ve kenar olmak üzere 2 ana bileșeni vardır [12]. SSekil 1.'de örnek bir çizge yapısı verilmiştir. Çizgeler(Graph) Ç= $(\mathrm{D}, \mathrm{K})$ biçiminde tanımlanmaktadır. D düğüm kümesini simgelerken, $\mathrm{K}$ ise düğümler arasındaki bağlantıyı sağlayan kenar kümesidir [12].

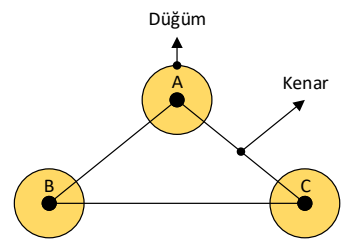

Şekil 1. Örnek çizge yapısı

Çizgeler bağlantı yönlerine göre yönlü, yönsüz ve karışık olmak üzere isimlendirilmektedir. Bu çalışmada aralarında bağlantı bulunan her iki düğümünde birbirini etkilediği yönsüz çizgeler üzerinde gerçekleştirilecektir.

\subsection{Popüler çizge algoritmaları}

Çizgeler üzerinde birçok problemin çözümü için algoritmalar geliştirilmiştir. Çizge üzerindeki etkili dügüumlerin belirlenmesi, dügümler arasındaki en kısa yolun hesaplanması, düğümler arasında oluşan topluluklarının tespiti ve henüz gerçekleșmemiş olan bağlantıların tahmini gibi problemler örnek olarak gösterilebilir. $\mathrm{Bu}$ problemlere çözüm olarak geliștirilmiş algoritmalardan bazıları; Degree, Closeness, PageRank, Eigenvector merkezlilik ölçütleri çizge üzerindeki düğümlerin etkili olma değerlerinin tespit edilmesinde[13], Prim, kruskal, bellman ford algoritmaları düğümler arasındaki en kısa yolun belirlenmesinde [13], Jaccard, cosine, euclidean algoritmaları düğümlerin birbirlerine olan benzerliklerinin tespit edilmesinde[13], Louvain, label 
propagation algoritmaları düğüm gruplarının çizge içerisinde nasıl kümelendiğini tespit etmek için kullanılmaktadır [13].

\subsubsection{Pagerank merkezlilik ölçütü}

Pagerank merkezlilik ölçütü Larry Page ve Sergey Brin tarafından 1998 yılında Standford Üniversitesinde geliştirilmiştir. Temel amacı web sayfalarının bağlantılarını tespit etmek ve arama motorlarında aranan içeriklere daha doğru bir şekilde yönlendirme sağlamak için web sayfalarının kalitelerini hesaplamaktır. Pagerank yönlendirilmiş bir çizgedeki düğümlerin etkisini ve önemini ölçen bir algoritmadır. Gelen bağlantı sayısı ve kaynak düğümün önemine göre her bir düğümün puanını yinelemeli bir şekilde komşularına dağıtarak hesaplanmaktadır. Teorik olarak bu durum rastgele bir şekilde çizgeyi bir baştan bir bașa incelemeye denktir. Daha sade bir ifade ile açıklanacak olursa bir düğümün önemi yalnızca kendisine bağlantı sağlayan düğümlerin önemi kadar olduğudur [14]. Merkezlilik ölçütünün genel formülü aşağıda Denklem (1) de verilmiştir.

$P R(A)=(1-d)+d\left(\frac{P R(t 1)}{C(t 1)}+. .+\frac{P R(t n)}{C(t n)}\right)$

t1... tn: Değerini bulmak istediğimiz düğüme bağlantı veren düğümleri, PR(tn): Bize bağlantı veren düğümlerin kendi değerlerini, $\mathrm{C}(\mathrm{tn})$ : Her dügümün diğer dügümlere verdiği bağlantı sayısını, d: Tüm oranlar toplamının 1'i geçmesini engellemek için kullanılan katsayı (damping factor) [14].

\subsubsection{Closeness merkezlilik ölçütü}

Closeness merkezlilik ölçütü her düğümün diğer bütün düğümlere olan uzaklıkları hesaplanarak tüm dügüm çiftleri arasında en kısa yolların hesaplanmasına dayanmaktadır. Elde edilen sonuç ters çevrilerek ilgili düğüm için Closeness merkezlilik ölçütü değerini hesaplamak için ters çevrilir. Puanı yüksek olan düğümler diğer tüm dügümlere en kısa mesafelere sahiptir [15]. Algoritmaya ait formül Denklem (2) de ve Denklem (3) verilmiştir.

mesafe $[u]=\sum_{d_{\zeta,}(u, v) \neq \infty}^{u \in D} d_{C}(u, v)$

Ç= $=(D, K)$ için $u \in$ D olmak üzere mesafe [u] ilgili düğümün diğer düğümlere olan mesafe toplamını ifade etmektedir. Denklem (3) de belirtilen $\mathrm{cc}[\mathrm{u}]$ ise ilgili dügüme ait Closeness merkezlilik değerini hesaplamaktadır [15]. $c c[u] \frac{1}{\text { mesafe }[u]}$

\subsubsection{Eigenvector merkezlilik ölçütü}

1987 yılında Phillip Bonacich tarafından önerildi. Eigenvector merkezlilik ölçütü düğümlerin geçiş etkisini ve bağlantılarını ölçen bir yöntemdir. Yüksek puanlı dügümler ile ilişkiler düşük puanlı düğümlerin bağlantılarından daha fazla katkı sağlamaktadır. Bu durum yüksek puana sahip dügümün başka bir yüksek puana sahip düğüme bağlandığını gösterir [16]. Denklem (4) ve Denklem (5)'de merkezlilik ölçütüne ait genel formül verilmiştir. Formülde verilen ifadelerden A, çizgeye ait bitişiklik matrisini, $\lambda$ ise A matrisinin en büyük özdeğer vektörüdür [16].

$$
\begin{aligned}
& A x=\lambda x, \quad \lambda x_{i}=\sum_{j=1}^{n} a_{i j} x_{j}, \quad i=1, \ldots, n \\
& c(\beta)=\sum_{k=1}^{\infty} \beta^{k-1} A^{k} 1, \quad|\beta|<1 / \lambda
\end{aligned}
$$

\subsubsection{Degree merkezlilik ölçütü}

Degree merkezlilik ölçütü Linton C.Freeman tarafından 1979 senesinde sosyal ağlarda merkeziyet kavramına ait yapmış olduğu bir makalede önerilmiştir. Ölçüt bir düğüme gelen ve giden bağlantıların sayısını ölçmektedir. Yöntem bireysel düğümlerin popülaritesini bulmak için kullanılırken, aynı zamanda bütün çizgedeki en küçük dereceleri, en büyük dereceleri, orta dereceleri ve standart sapma değerlerini tespit etmek için kullanılmaktadır [17].

\section{2. Önerilen yöntem(Karcı merkezlilik ölçütü)}

Herhangi bir çizgedeki etkili düğümlerin belirlenmesi için önerdiğimiz yeni yaklaşım 3 temel aşamadan oluşmaktadır. İlk olarak çizge üzerinde tanımlı bütün düğümlerin dereceleri hesaplanmaktadır. Düğüm dereceleri çizge üzerindeki düğümlere bağlı olan kenar bağlantı sayısı olarak ifade edilmektedir. Șekil 2.'de belirtilmiştir. A dügümünün 3 kenar bağlantısı olduğu için derecesi 3'dür denir, $B=4, C=4, D=2$, $\mathrm{E}=2, \mathrm{~F}=3$ dür. Sonraki aşamada çizgeye ait K-Max tree(Karcı Maksimum Ağacı) olușturularak bu ağaç üzerinde düğümlerin dereceleri hesaplanmaktadır. K-Max tree oluşturma sürecinde düğüm derecesi büyük olan düğümden başlanarak çizgedeki bütün düğümlerin dolaşılmasına dayanmaktadır [18]. Seçilen büyük dereceli düğümün komşuları indeks sırasına göre kuyruğa atılır ve bir sonraki 
maksimum düğüm seçimi bu kuyruk üzerinden yapilır.

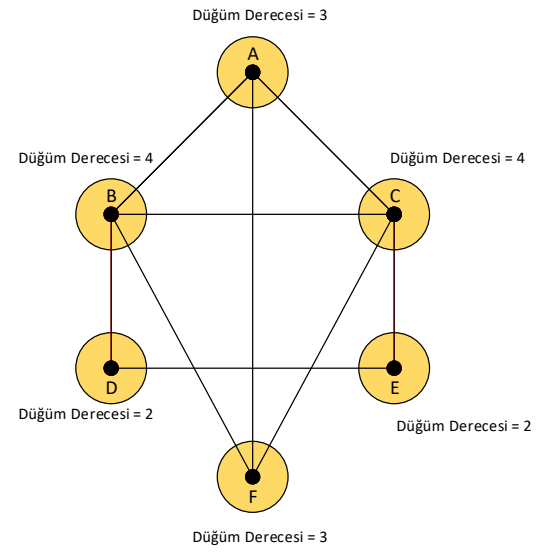

Şekil 2. Çizge üzerindeki düğüm dereceleri

Burada seçim yapılırken diğer önemli kriter kuyrukta birden fazla maksimum düğüm derecesine sahip iki veya daha fazla düğüm var ise önce kmax tree deki ağaç seviyesinde bakılır ve ağaç seviyesi düşük olan düğüm bir sonraki açlacak düğüm olarak seçilir. Eğer maksimum düğümlerin ağaç seviyeleri eşitse kuyruktaki sıralamasına göre seçim gerçekleştirilir. Ulaşılan düğümlere artık başka düğümlerden ulaşılmaya gerek duyulmadığından, ulaşılan düğümlerin diğer düğümler ile olan bağlantıları silinerek kuyruktaki düğümlerin dereceleri güncellenmektedir. Şekil 2.'de verilen çizge üzerinde açlklayacak olursak, ilk olarak çizge üzerindeki en yüksek dereceli dügüm tespit edilir. Örnek olarak kullandığımız Șekil 2. deki çizgede $B$ ve $C$ düğümleri 4 dügüm derecesi ile en yüksek değere sahiptir. Eşitlik olduğu için B ve $C$ düğümlerinden herhangi birisi seçilebilir. C düğümünün seçildiği göz önünde bulundurularak C'nin komșularına ulașılır. C dügümü çizgeden çıkarılır ve dügüm dereceleri güncellenir. Tablo 1.'de $\mathrm{C}$ düğümünün çizgeden çıkarılması sonrası düğümlere ait güncel dereceler verilmiştir.

Tablo 1. Kmax tree kuyruk birinci iterasyon.

\begin{tabular}{lcccccc} 
Dügüm no & $A$ & $B$ & $C$ & $D$ & $E$ & $F$ \\
\hline Kuyruk no & 1 & 2 & & & 3 & 4 \\
Düğüm derece & 2 & 3 & & & 1 & 2 \\
\hline
\end{tabular}

1. iterasyon itibari ile $\mathrm{D}$ dügüumüne henüz ulaşılmadığı için kuyruğa eklenmemiştir. C dügüumünden $\mathrm{A}, \mathrm{B}, \mathrm{F}, \mathrm{E}$ dügüumlerine ulașılmıștır. A, B, F, E düğümlerine başka bir düğüm üzerinden ulaşılmasına gerek olmadığı için ulașılan düğümlerin kendi aralarındaki bağlantıları silinir. Silinme işlemi sonrasında Tablo 2.'de belirtildiği şekilde kuyruk güncellenir. A ve $\mathrm{F}$ düğümlerinin derecesi 0 olarak gözükmesinin sebebi bu iki düğüm üzerinden artık ulaşılabilecek herhangi bir dügüm bulunmamasıdır. $\mathrm{B}$ ve $\mathrm{E}$ düğümlerinin düğüm derecesi 1 olarak hesaplanmıștır. $\mathrm{Bu}$ ifade iki düğümünde daha önce ulaşılmayan bir dügüme bağlantısı olduğunu belirtmektedir. Kuyruktaki maksimum düğümü ifade eden bu düğümlerin derecelerin eșit olduğu için önce ağaçdaki seviyesine bakılır. İki düğümün ağaç seviyeleri 1 olduğu için kuyruktaki sırasına bakılara açılıma devam edilir. Kuyruk sırasında $\mathrm{B}$ düğümü $\mathrm{E}$ düğümünden önde olduğu için 2 . maksimum dügüm olarak B düğümü seçilmiştir. $B$ düğümü üzerinden ulaşılan dügümler yine aynı şekilde kuyruğun sonuna eklenir. B düğümünden $\mathrm{D}$ düğümüne ulaşllarak çizge üzerindeki bütün düğümlere ulaşılmıș ve Kmax tree ağacı oluşturma süreci tamamlanmıştır.

Tablo 2. Kmax tree kuyruğu güncelleme.

\begin{tabular}{lcccccc} 
Dügüm no & $A$ & $B$ & $C$ & $D$ & $E$ & $F$ \\
\hline Kuyruk no & 1 & 2 & & & 3 & 4 \\
Düğüm derece & 0 & 1 & & & 1 & 0 \\
\hline
\end{tabular}

Şekil 3.'de çizgeye ait Kmax tree yapısı verilmiștir. Önerdiğimiz yöntemde kullanılacak bir diğer parametre olan Kmax tree düğüm dereceleri Tablo 3.'de verilmiștir.

Tablo 3. Kmax tree dügüm dereceleri.

\begin{tabular}{lllllll}
\hline Düğüm no & $A$ & $B$ & $C$ & $D$ & $E$ & $F$ \\
\hline Düğüm derece & 1 & 2 & 4 & 1 & 1 & 1 \\
\hline
\end{tabular}

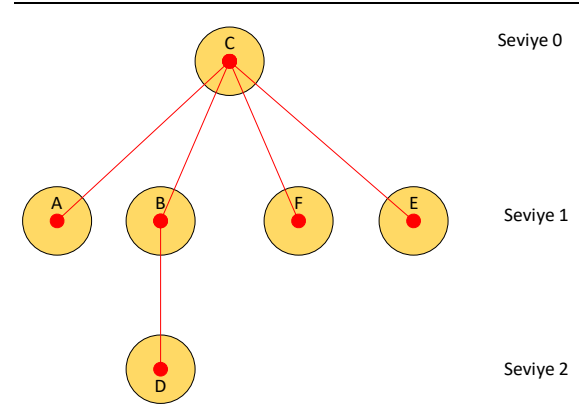

Şekil 3. K-Max Tree 
Son așamada Kmax tree çizge üzerindeki bütün kenarlar tek tek kesilerek Kmax çizge her kesme işlemi sonrası 2 kümeye ayrılmıștır. Çizge kesme ișlemi sırasında sadece bir kırmızı kenar üzerinden geçilecek şekilde yapılacaktır. Bunun sonucu olarak Kmax tree deki kenar sayısı kadar kesme ișlemi yapılarak çizge her kesme ișlemi sonunda 2 kümeye ayrılmaktadır. Bu iki kümeyi olușturan düğümlerin karșı küme ile bağlantıları hesaplanarak hangi dügüm ile bağlantısı var ise onun kesme değerine eklenmektedir. Şekil 4.'de çizge üzerindeki kesme işleminin nasıl yapıldığ ifade eden bir görsel verilmiştir. Bu kesme işlemleri neticesinde düğümlere kesme dereceleri kazandırmaktadır. $\mathrm{Bu}$ kesme dereceleri etkili düğümün belirlenmesi için en önemli parametreyi oluşturmaktadır.

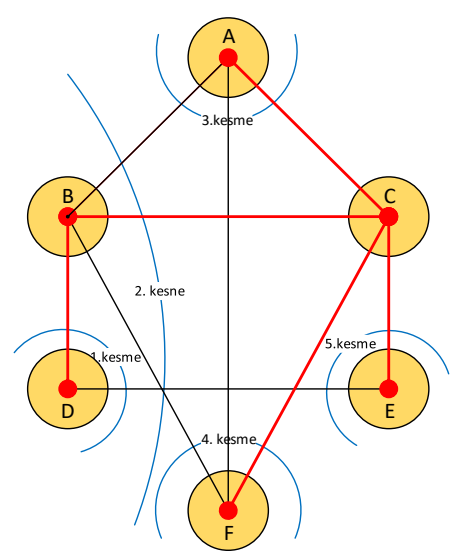

Şekil 4. Temel kesmeler

Şekil 4.'de verilen yapıyı açılklayacak olursak, 1. kesme $\mathrm{D}$ düğümünü çizgenin geri kalanından ayırarak 1. küme $\{D\}-2$. küme $\{A, B, C, E, F\}$ șekilde 2 kümeye dönüştürmektedir. $\mathrm{Bu}$ iki küme arasındaki kenar bağlantılarına bakılır. 1. kesmenin gerçekleșmesi neticesinde $B$ ile D düğümleri arasındaki kenar ile $\mathrm{D}$ ile $\mathrm{E}$ düğümlerin arasında kenar etkilenmiștir. Bunun neticesinde $\mathrm{B}$ ve $\mathrm{E}$ düğümü 1 , $\mathrm{D}$ düğümü ise 2 kesme derecesi kazanmıștır. 2. Kesme ișlemi \{B, $D\}$ ve $\{A, C, E, F\}$ düğümlerini iki ayrı kümeye ayırmaktadır. Bu işlem sonucunda A ile B, B ile C, $B$ ile $F, D$ ile $E$ düğümleri arasındaki kenar kesilmiștir. Kesme sonrasında A, C, D, E, F düğümleri 1 kesme derecesi alırken $B$ dügümü 3 kesme derecesi almıştır. Aynı işlem diğer kesmeler doğrultusunda gerçekleştirildiğinde 3 . kesme $B, C$ ve $F$ düğümlerine 1 , A düğümüne 3 kesme derecesi kazandırmıştır. 4. kesme A, B, C düğümlerine $1, \mathrm{~F}$ düğümüne 3 kesme derecesi kazandırmaktadır. 5. kesme ise C ve D düğümlerine 1, E dügümüne 2 kesme derecesi kazandırmaktadır. Tablo 4.'de bütün kesme dereceleri verilmiștir.

Tablo 4. Tüm düğ̈̈mlere ait kesme dereceleri

\begin{tabular}{|c|c|c|c|c|c|c|c|}
\hline Düğüm no & & $A$ & $B$ & C & D & $E$ & $F$ \\
\hline 1.Kesme & & - & 1 & - & 2 & 1 & - \\
\hline 2.Kesme & & 1 & 3 & 1 & 1 & 1 & 1 \\
\hline 3.Kesme & & 3 & 1 & 1 & - & - & 1 \\
\hline 4.Kesme & & 1 & 1 & 1 & - & - & 3 \\
\hline 5.Kesme & & - & - & 1 & 1 & 2 & - \\
\hline $\begin{array}{l}\text { Toplam } \\
\text { Dereceleri }\end{array}$ & Kesme & 5 & 6 & 4 & 4 & 4 & 5 \\
\hline
\end{tabular}

$\mathrm{Bu}$ aşamada etkili düğümün belirlenmesi için bütün hesaplama işlemleri yapılmıştır. Önerdiğimiz yaklașım bir çizge üzerindeki etkili dügümün belirlenmesi için çizge dügüm dereceleri, Kmax tree dereceleri ve Kesme düğüm derecelerinin toplamından oluşmaktadır. Önerilen merkezlilik algoritması "Karcl merkezlilik ölçütü" olarak isimlendirilmiștir ve " $\Gamma$ " işareti Karcı merkezlilik değerini ifade etmektedir.

Karcı merkezlilik değeri $(\Gamma)=$ Çizge $_{\text {düğüm derecesi }}$

+ Kmax tree dŭğüm derecesi + Kesme derecesi $_{\text {d }}$

$\mathrm{Bu}$ formül uygulandığında örnek çizgeye ait düğümlerin etkili olma değerleri( $(\Gamma)$ Tablo 5.'de gösterildiği şekilde elde edilmiştir. Tablo 5. incelendiğinde çizgedeki en etkili dügümlerin 12 değeri ile $B$ ve $C$ dügümlerinin olduğu tespit edilmiștir. Bu düğümleri 9 etkili olma değeri ile A ile F dügümleri ve 7 etkili olma değeri ile D ve E düğümleri takip etmektedir.

Tablo 5. Düğümlere ait etkili olma değerleri

\begin{tabular}{lcccccc}
\hline Düğüm no & $A$ & $B$ & $C$ & $D$ & $E$ & $F$ \\
\hline Düğüm dereceleri & 3 & 4 & 4 & 2 & 2 & 3 \\
Kmax tree dereceleri & 1 & 2 & 4 & 1 & 1 & 1 \\
Kesme dereceleri & 5 & 6 & 4 & 4 & 4 & 5 \\
$\Gamma$ & 9 & 12 & 12 & 7 & 7 & 9
\end{tabular}


DEÜ FMD 24(70), 143-155, 2022

Önerilen algoritma R dilinde yazılmıștır. Etkili düğüm değerlerinin gerçekleștirildiği algoritmanın en kritik adımlarını içeren kod blokları așağıda kısmi biçiminde verilmiștir.

Algoritmaya ait düğüm dereceleri ve kesme derecelerinin oluşturulduğu kısmi kod blokları

\#\# "g" çizgeyi ifade etmektedir.

\#\# "KmaxTree" g çizgesinden oluşturulan Kmax tree yi ifade etmektedir.

KmaxTreelist <- as_edgelist(KmaxTree,names = TRUE)

KmaxTreelistvector

as.data.frame.array(KmaxTreelist)

\#\#\# Verilen çizgenin derecesini hesaplayan metod

GrafDugumDereceHesaplama <- function(x)\{

$\operatorname{return}(\operatorname{degree}(\mathrm{x}))\}$

\#\# g grafının KmaxTree ye göre kesme derecelerinin hesaplandığı metod

GrafKesmeHesaplama <- function( $\{$ \{

$\mathrm{j}<-1$

kesmelertoplam $<-0 *($ degree $(\mathrm{g}))$

while $(\mathrm{j}<=$ length(KmaxTreelistvector\$V1) ) \{

\#\# her iterasyonda KmaxTree deki farklı bir kenar kesilir.

guncelKmax <- delete.edges(KmaxTree, $\mathrm{E}($ KmaxTree, $\mathrm{P}=\mathrm{c}($ KmaxTreelistvector\$V1[j],KmaxTreeli stvector\$V2[j])) )

\#\# Kesilme sonrası 2 ayrı küme oluşturulmaktadır. ayrigruplar <- groups(components(guncelKmax))

$\mathrm{ab}=$ data.frame $(\mathrm{c}($ ayrigruplar[1] $))$

$\mathrm{cd}=$ data.frame $(\mathrm{c}($ ayrigruplar[2])

kartezyen $=$ cartesianExpand $(\mathrm{ab}, \mathrm{cd})$

g1 <- graph.empty (directed $=$ FALSE $)$

$\mathrm{i}<-1$

\#\# 2 ayrı kümedeki düğümlerin birbirleri ile olan kenar bağlantıları kartezyen çarpım ile oluşturularak, g çizgesindeki bağlantıları kesișenler bize etkilenen düğümleri vermektedir. Bu işlemi gerçekleştiren kod bloğu aşağıda verilmiştir.

while (i <= length(kartezyen\$X1)) \{

gecici <- graph(edges <- c(kartezyen $\$ \mathrm{X} 1[\mathrm{i}]$

kartezyen $\$ \mathrm{X} 2[\mathrm{i}]$ ), directed $=$ FALSE)

g1 <- (g1\%u\% gecici) \# grafın birleștirilmesi

$\mathrm{i}=\mathrm{i}+1\}$

kesisimlist <- intersection(g,g1)

$j=j+1$

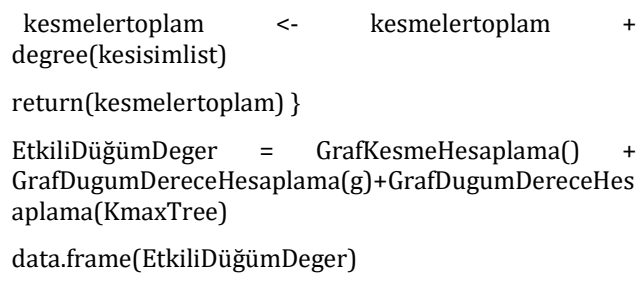

Önerdiğimiz algoritmanın kesme derecelerinin hesaplanması algoritmanın en kritik ve maliyetli kısmını oluşturmaktadır. Kesme derecelerinin hesaplandığı metodun zaman karmaşıklığı $\mathrm{O}\left(n^{3}\right)$ dür [18]. Bu yüzden algoritmanın geneline ait zaman karmaşıklığı $\mathrm{O}\left(n^{3}\right)$ olmaktadır.

\section{Bulgular}

Önceki bölümde algoritmanın çalışma prensiplerinden bahsedilmiștir. $\mathrm{Bu}$ kısımda örnek bir çizge üzerinde algoritma aşamaları kısaca verilerek merkezlilik ölçütünün çıtıları incelenecektir. Aynı örnek çizge üzerinde literatürde oldukça yaygın olarak kullanılan 4 farklı etkili dügüm keșfetme ölçütü uygulanarak bu ölçütlerin karşıllaştırmalı sonuçlarına yer verilecektir. Her ölçütün etkili düğüm değerlerini belirlerken ana kriterlerinin neler olduğundan bahsedilecektir. Bu bölümde örnek olarak kullanılan çizge Şekil 5.'de belirtildiği üzere 20 düğüm ve 33 kenardan oluşmaktadır.

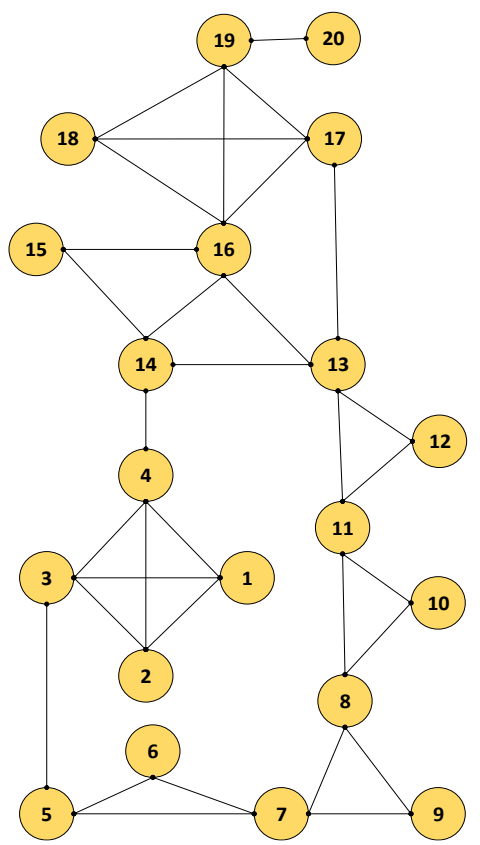

Şekil 5. Örnek çizge 
Şekil 6.'da örnek çizgeye ait Kmax tree yapısı verilmiştir.

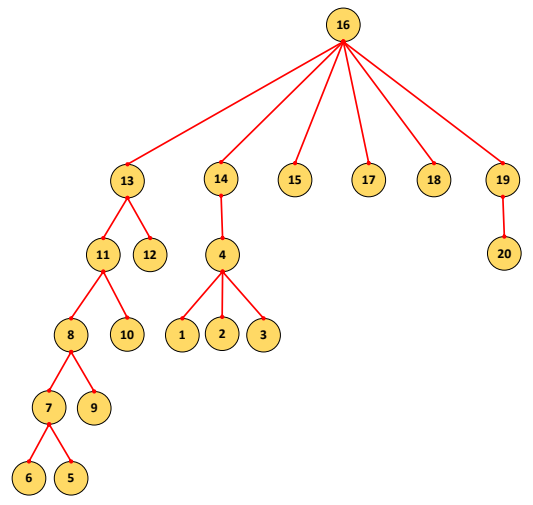

Seviye 0

Şekil 6. Kmax tree

Belirlenen Kmax tree neticesinde çizge üzerinde gerçekleştirilen bütün kesme işlemleri Şekil 7.'de verilmiştir. Örnek çizge için 19 temel kesme oluşmaktadır. Bu kesmelerin her biri üzerinden geçen kenarları keserek çizgeyi 2 ayrı kümeye ayırmaktadır.

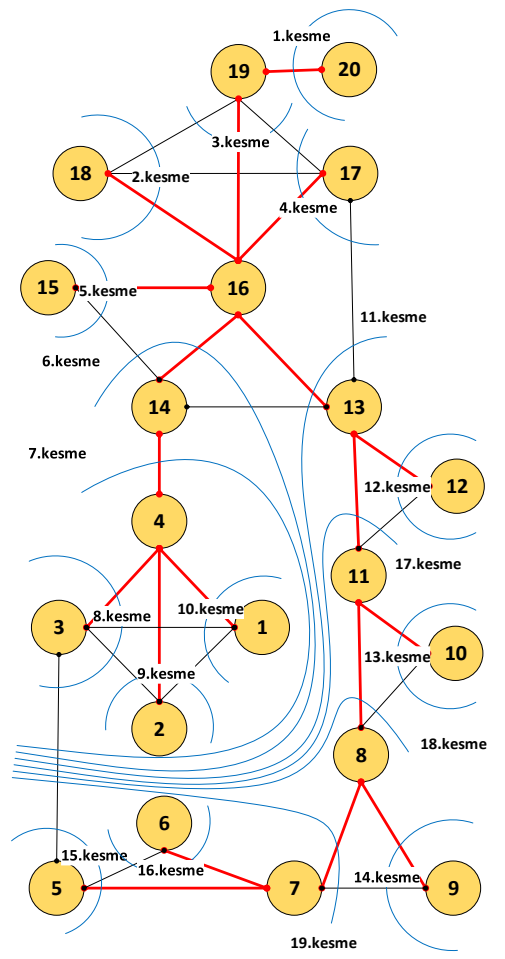

Şekil 7. Çizgedeki bütün kesmeler

3 aşamanın tamamlanması ile elde edilen sonuçlar toplanarak graf üzerindeki düğümlerin etkili olma değerleri hesaplanmıștır. Tablo 6.'da algoritmanın düğüm dereceleri, Kmax tree dereceleri, kesme dereceleri ve düğümlerin etkili olma değerleri verilmiştir. Yüksek etkili olma değerine sahip olan dügümler için çizgede konum olarak ve bağlantıları açısından en kritik yapıda olduğu söylenebilir. Etkili olma değeri yüksek olan düğüm çizge içerisinde daha baskındır diyebiliriz. Bu sonuçlara göre çizge üzerindeki en etkili 4 düğüm büyükten küçüğe olacak şekilde sırası ile 3, 16, 5, 13 olarak tespit edilmiştir.

Tablo 6. Önerilen algoritmaya ait sonuçlar

\begin{tabular}{|c|c|c|c|c|}
\hline $\begin{array}{c}\text { Düğüm } \\
\text { adı }\end{array}$ & $\begin{array}{l}\text { Düğüm } \\
\text { derece }\end{array}$ & $\begin{array}{c}\text { Kmax } \\
\text { tree } \\
\text { derece }\end{array}$ & $\begin{array}{l}\text { Kesme } \\
\text { derece }\end{array}$ & $\Gamma$ \\
\hline 1 & 3 & 1 & 5 & 9 \\
\hline 2 & 3 & 1 & 5 & 9 \\
\hline 3 & 4 & 1 & 13 & 18 \\
\hline 4 & 4 & 4 & 4 & 12 \\
\hline 5 & 3 & 1 & 11 & 15 \\
\hline 6 & 2 & 1 & 3 & 6 \\
\hline 7 & 4 & 3 & 5 & 12 \\
\hline 8 & 4 & 3 & 5 & 12 \\
\hline 9 & 2 & 1 & 3 & 6 \\
\hline 10 & 2 & 1 & 3 & 6 \\
\hline 11 & 4 & 3 & 5 & 12 \\
\hline 12 & 2 & 1 & 3 & 6 \\
\hline 13 & 5 & 3 & 7 & 15 \\
\hline 14 & 4 & 2 & 6 & 12 \\
\hline 15 & 2 & 1 & 3 & 6 \\
\hline 16 & 6 & 6 & 6 & 18 \\
\hline 17 & 4 & 1 & 7 & 12 \\
\hline 18 & 3 & 1 & 5 & 9 \\
\hline 19 & 4 & 2 & 6 & 12 \\
\hline 20 & 1 & 1 & 1 & 3 \\
\hline
\end{tabular}


Aynı çizge üzerinde PageRank, Eigen, Closeness ve Degree merkezlilik ölçütleri uygulanmıș ve sonuçlar Tablo 7.'de karşılaştırmalı olarak verilmiştir. Pagerank ölçütüne göre çizge üzerindeki en etkili düğümlerin sıralaması büyükten küçüğe olacak şekilde 16, 13, 7, 8 olarak tespit edilmiştir. Pagerank ölçütü düğümlerin çizge içerisindeki etkili olma durumlarını hesaplarken komșu düğümlerden kendisine gelen bağlantıların ne kadar yüksek olduğu ile ilgilenmektedir. Örnek olarak kullanılan çizge yönsüz olduğu için algoritma hesaplama işlemlerini çift yönlü kenar bağlantıları olarak hesaplamıștır. Closeness ölçütüne göre en etkili 4 dügümün sıralaması büyükten küçüğe olacak şekilde 13, 14, 16, 11 olarak tespit edilmiştir. Closeness ölçütü bütün düğümlere en yakın düğümlerin daha etkili olduğunu söylemektedir. Bu yaklașım çizgenin merkezine yakın olan dügümlerin daha etkin olduğu sonucunu bize vermektedir. Eigenvector ölçütüne göre en etkili 4 dügümün sıralaması büyükten küçüğe olacak şekilde 16, 17, 13, 19 olarak hesaplanmıștır. Eigenvector ölçütü düğümlerin çizgedeki etkili olma durumlarını hesaplarken her düğümün komșusunun ne kadar etkili olduğunu göz gönünde bulundurmaktadır. İlgili dügümün komșuları ne kadar etkili ise kendisi o kadar etkilidir. Degree ölçütüne göre etkili düğüm sıralaması en etkiliden, en etkisize olacak şekilde ilk iki sırayı 16. ve 13. dügümler oluştururken 3 . ve 4 . sırayı eşit düğüm derecesine sahip olan $3,4,7,8,11$, 14, 17, 19 düğümleri olușturmaktadır. Degree ölçütü düğümlerin kaç adet bağlantısı olduğuyla ilgilenmektedir. Tüm merkezlilik ölçütlerine ait sonuçlar incelendiğinde çizge içerisindeki dügümlerin etkili olma sıralamalarının kısmi benzerlik gösterdiği görülmektedir. 16. ve 13 . düğümün bütün algoritmalarda ilk 4 etkin düğüm içerisinde olduğu görülürken, 20. ve 6 . düğümler en etkisiz düğümler sıralamasında başı çekmektedir. Her merkezlilik ölçütü kendine has değerlendirme özelliğinden dolayı farklı düğümleri etkinlik sıralamasında öne çlkarabilmektedir. Önemli olan hangi problem türü için hangi yöntemin tercih edileceğidir. Çizgedeki düğümlerin etkili olma değerlerini hesaplamak için geliștirilen her yöntemin, çözüm için odaklandığı farklı yaklașımlar olduğundan dolayı bu merkezlilik ölçütlerinin sonuçları arasında benzerlik beklemek çok doğru olmayacaktır. Her yöntem kendi çözüm yaklaşımına uygun problemlerin çözümünde daha bașarılı olacaktır. Pagerank ölçütü web sitelerinin birbirine gönderdikleri link sayılarını göz önünde bulundurarak web de arama yapan kişilere doğru sitelere yönlendirmede kullanırlırken, closeness ölçütü ulaşım sistemleri gibi konumsal etkililiğin önemli olduğu problem türlerinde bașarılı sonuçlar vermektedir, eigenvector ölçütü ise sosyal ağlarda bireylerin ağ içerisinde ne kadar etkili veya baskın olduğunu belirlemek için başarıyla kullanılmaktadır.

Sunduğumuz algoritmada düğümlerin etkili olma değerlerini büyük oranda Kmax ağacı etkilemektedir. Kmax ağacı çizgedeki kesme derecelerinin kaynağıdır. Kmax tree yüksek dereceye sahip düğümlerin kök düğüme(root node) yakın olanlarının açılım önceliği olan özel bir dolanım ağacıdır. Temel amaç en az sayıda ağaç seviyesi ile tüm düğümlere ulaşmaktır. Bizim sunduğumuz yaklaşımın temel odak noktası gerçekleștirilen kesmeler neticesinde çizgedeki hangi dügümün ne kadar etkilendiğidir. Çok etkilenen dügümlerin etkili olma değerleri daha yüksek olmaktadır. Ĕger kesme neticesinde çizge kritik bir bölgeden ayrılmıșsa daha fazla düğüm bu kesme ișleminden etkilendiği sonucunda ulaşılmaktadır. Bu kritik bölgeyle bağlantısı olan düğümler çizge içerisinde daha kritik konumda bulunmaktadır. Önerdiğimiz algoritma çizgenin genel yapısı düșünüldüğünde kilit noktada bulunan düğümlerin tespit edilmesinde önemli faydalar sağlamaktadır.

Önerdiğimiz merkezlilik ölçütü ve diğer etkili düğüm belirleme ölçütleri ile 70 düğüm ve 133 kenar bağlantısına sahip bașka bir örnek çizge üzerinde uygulanarak merkezlilik ölçütlerinin farklı çizge türlerindeki yaklașımları incelenmiştir. Şekil 8.'de örnek çizgeye ait görsel verilmiștir. Örnek çizgedeki düğüm noktalarının boyutları yeni önermiș olduğumuz merkezlilik ölçütüne göre dügümlerin çizge içerisindeki etkili olma durumunu belirtmektedir. Boyutu büyük olan düğümler için daha etkili veya daha kritik konumdaki düğümlerdir diyebiliriz. Pagerank, closeness, eigenvector ve degree ölçütleri şekil 8.'deki çizgeye uygulanmış ve her ölçüte göre en etkili ve en etkisiz 8 düğüme ait değerler Tablo 8. ve Tablo 9. da verilmiștir. Tablo 8. incelendiğinde 60. düğüm önerdiğimiz Karcl merkezlilik ölçütüne göre en etkili düğüm olarak belirlenmiştir. 60. Dügüm aynı zamanda pagerank ölçütüne göre en etkili düğüm 
sıralamasında 7. sirada bulunmaktadır. Pagerank ölçütüne göre çizgedeki en etkili düğüm 7. düğüm olarak tespit edilmiştir. 7. düğüm degree ölçütüne göre 5 . sırada bulunmaktadır. 26. düğüm closeness ölçütü için 1. sırada, pagerank ölçütü için 3. sırada, eigenvector ve degree ölçütü için 2. sırada bulunmaktadır. 16. düğüm ise eigenvector ve degree ölçütleri için en etkili düğüm iken pagerank ölçütü için 2. en etkili dügüum olarak tespit edilmiştir. 16. Düğüm closeness ve karcı ölçütüne göre en etkili ilk 8 dügüm içerisinde yer alamamıștır.

Tablo 7. Merkezlilik ölçütleri sonuçlar

\begin{tabular}{|c|c|c|c|c|c|}
\hline Düğüm No & Pagerank & Closeness & Eigenvector & Degree & $\begin{array}{r}\text { Karcl } \\
(\Gamma)\end{array}$ \\
\hline 1 & 0,04500409 & 0,3166667 & 0,16050265 & 3 & 9 \\
\hline 2 & 0,04500409 & 0,3166667 & 0,16050265 & 3 & 9 \\
\hline 3 & 0,05896306 & 0,3518519 & 0,17658369 & 4 & 18 \\
\hline 4 & 0,05752132 & 0,3877551 & 0,29036675 & 4 & 12 \\
\hline 5 & 0,04848517 & 0,3220339 & 0,07894665 & 3 & 15 \\
\hline 6 & 0,03487227 & 0,2753623 & 0,04297744 & 2 & 6 \\
\hline 7 & 0,06416379 & 0,3275862 & 0,08906506 & 4 & 12 \\
\hline 8 & 0,06315235 & 0,3584906 & 0,16202827 & 4 & 12 \\
\hline 9 & 0,03455468 & 0,2968750 & 0,06422973 & 2 & 6 \\
\hline 10 & 0,03386083 & 0,3166667 & 0,13080289 & 2 & 6 \\
\hline 11 & 0,06089860 & 0,3958333 & 0,34931952 & 4 & 12 \\
\hline 12 & 0,03230093 & 0,3518519 & 0,28967127 & 2 & 6 \\
\hline 13 & 0,06976457 & 0,4418605 & 0,78309255 & 5 & 15 \\
\hline 14 & 0,05642047 & 0,4318182 & 0,63754191 & 4 & 12 \\
\hline 15 & 0,03110636 & 0,3333333 & 0,41888361 & 2 & 6 \\
\hline 16 & 0,08200242 & 0,4130435 & 1 & 6 & 18 \\
\hline 17 & 0,05642052 & 0,3584906 & 0,7848114 & 4 & 12 \\
\hline 18 & 0,04406486 & 0,3114754 & 0,62529936 & 3 & 9 \\
\hline 19 & 0,06098113 & 0,3166667 & 0,6596717 & 4 & 12 \\
\hline 20 & 0,02045849 & 0,2435897 & 0,16874418 & 1 & 3 \\
\hline
\end{tabular}




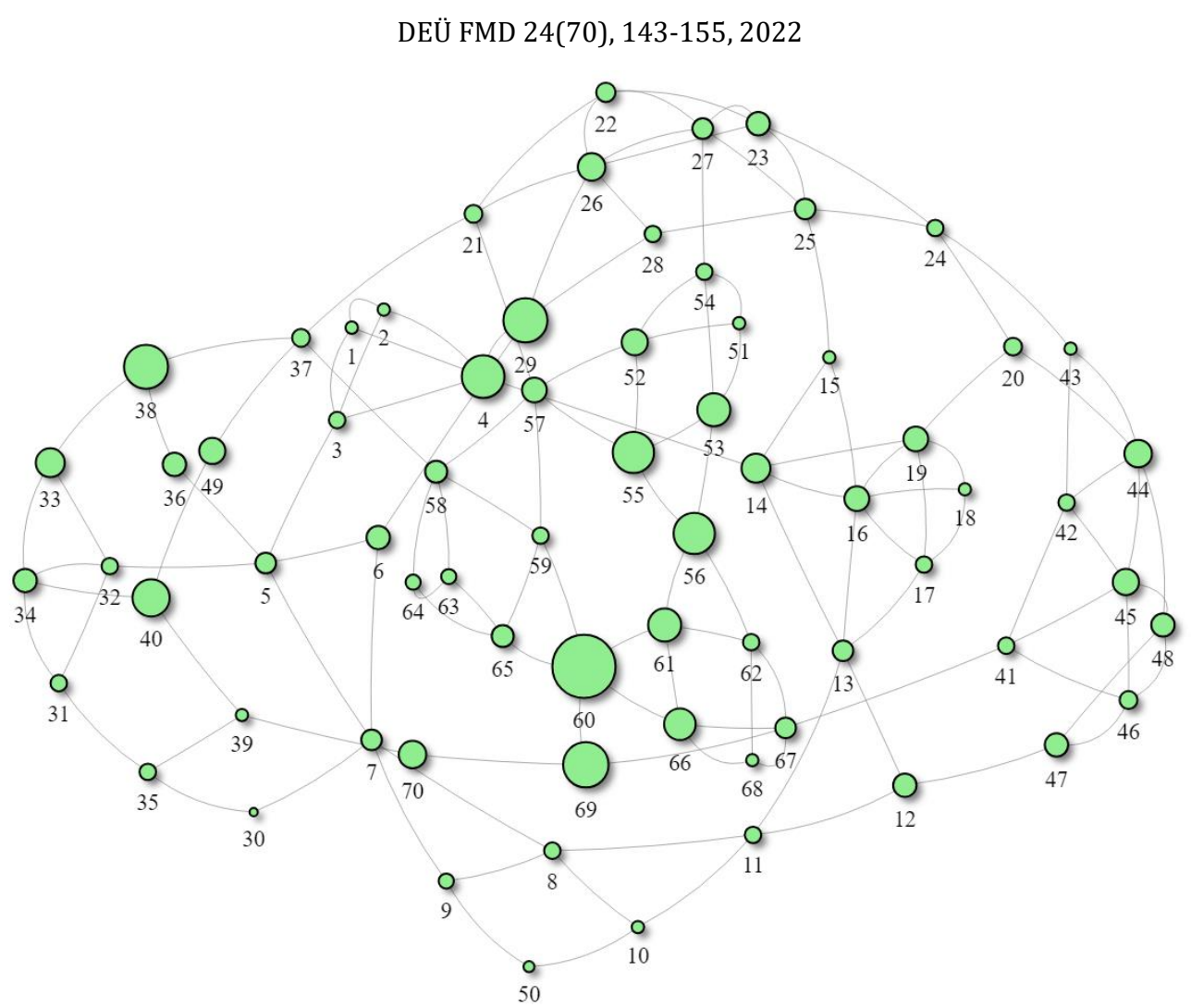

Şekil 8. Önerilen algoritma(Karcı merkezlilik ölçütü) ile çizge üzerindeki etkili düğümler

Tablo 8. Tüm merkezlilik ölçütlerine ait en etkili 8 düğüm

\begin{tabular}{cccccc}
\hline $\begin{array}{c}\text { Etkili } \\
\text { dügüm } \\
\text { siralamasl }\end{array}$ & Pagerank & Closeness & Eigenvector & Degree & Karcl $(\Gamma)$ \\
\hline 1 & 7 & 26 & 16 & 16 & 60 \\
2 & 16 & 29 & 26 & 26 & 69 \\
3 & 26 & 21 & 23 & 4 & 29 \\
4 & 5 & 23 & 27 & 5 & 38 \\
5 & 58 & 22 & 14 & 7 & 4 \\
6 & 67 & 27 & 19 & 13 & 55 \\
7 & 60 & 28 & 25 & 14 & 56 \\
8 & 4 & 25 & 17 & 19 & 40 \\
\hline
\end{tabular}


Tablo 9.'da her merkezlilik ölçütü için çizgedeki en etkisiz 8 düğüme ait bilgiler verilmiştir. Önerdiğimiz merkezlilik ölçütüne göre çizge içerisindeki en etkisiz düğüm 30. dügüümdür. 30. düğüm degree ölçütü içinde en etkisiz düğüm olarak tespit edilmiștir. Diğer ölçütlerin sonucuna göre 30 . düğüm pagerank için 3 . sırada, eigenvector için 7. sırada bulunan en etkisiz düğümdür. Tablodaki değerler incelendiğinde en etkisiz düğümler için büyük benzerlikler olduğu görülmektedir.

Tablo 9. Tüm merkezlilik ölçütlerine ait en etkisiz 8 düğüm

\begin{tabular}{|c|c|c|c|c|c|}
\hline $\begin{array}{c}\text { Etkisiz } \\
\text { düğüm } \\
\text { siralaması }\end{array}$ & Pagerank & Closeness & Eigenvector & Degree & $\operatorname{Karcl}(\Gamma)$ \\
\hline 1 & 36 & 50 & 39 & 30 & 30 \\
\hline 2 & 49 & 18 & 35 & 36 & 50 \\
\hline 3 & 30 & 10 & 70 & 49 & 1 \\
\hline 4 & 50 & 63 & 40 & 50 & 2 \\
\hline 5 & 70 & 64 & 31 & 70 & 10 \\
\hline 6 & 15 & 68 & 34 & 1 & 15 \\
\hline 7 & 18 & 31 & 30 & 2 & 18 \\
\hline 8 & 28 & 17 & 33 & 6 & 39 \\
\hline
\end{tabular}

\section{Tartışma ve Sonuç}

$\mathrm{Bu}$ çalışmada çizgeler üzerindeki etkili dügümlerin belirlenmesi için yeni bir merkezlilik ölçütü önerilmiştir. $\mathrm{Bu}$ yeni yöntemin tüm aşamaları örnek bir çizge üzerinde ayrıntılı olarak anlatılmış ve her aşamasına çalışmada uygulamalı olarak yer verilmiștir. Önerdiğimiz yöntemin 2 özgün yapısını oluşturan Kmax tree ve temel kesme derecelerinden bahsedilmiştir. Çizgelere nasıl uygulandığı ve sonuçları açıkça ifade edilmiștir. Düğümlerin etkili olma değerlerinin hesaplanmasına ait kısa kod blokları $\mathrm{R}$ dilinde verilerek, metodlar için öz bilgilendirmeler yapılmıştır. Aynı örnek çizge üzerinde pagerank, closeness, eigenvektör, degree merkezilik ölçütleri uygulanarak sonuçlar

\section{Kaynakça}

[1] Seker, S.E. 2015. Çizge Teorisi(Graph Theory). YBS Ansiklopedi, v.2. s. 17-29,

[2] Riaz, F. and Ali, K. M. 2011. Applications of Graph Theory in Computer Science. Third International Conference on Computational Intelligence, karşılaştırılmıștır. Her ölçütün kendine özgü çözüm yaklaşımına göre bazı ölçütlerde benzer sonuçlar olabileceği gibi bazı ölçütler arasında düşük benzerlik olacağı sonucuna ulaşılmıştır. Çalışmada önerilen yeni merkezlilik ölçütünün herhangi bir çizgedeki kilit konumda olan düğümlerin belirlenmesinde sağladığı başarı neticesinde literatüre önemli bir katkı yapacaktır. Yeni yöntemin sonraki aşamalarda minimum dominating setlerin(minimum hakim kümenin) ve Max cliq lerin belirlenmesi üzerine yapılacak çalışmalarda belirleyici parametrelerden birisi olacağı öngörülmektedir.

Communication Systems and Networks, Bali, s. 142-145. DOI: 10.1109/CICSyN.2011.40.

[3] Kenett, D.Y., Tumminello, M., Madi, A., GurGershgoren, G., Mantegna, R.N. and Ben-Jacob, E. 2010. Dominating Clasp of the Financial Sector Revealed by Partial Correlation Analysis of the Stock Market. PLOS ONE 20 Dec, DOI: 10.1371/journal.pone.0015032 


\section{DEÜ FMD 24(70), 143-155, 2022}

[4] Cozzens, M.B., Kelleher, L.L. 1988. Dominating sets in social network graphs, ELSEVIER Cilt. 16, Issue. 3, December, s. 267-279, DOI: 10.1016/0165-4896(88)90041-8

[5] Kintali, S. 2008. Betweenness Centrality : Algorithms and Lower Bounds, arxiv.org/abs/0809.1906v2, 19 Oct

[6] Xing, W. and Ghorbani, A. 2004. Weighted PageRank algorithm. Proceedings. Second Annual Conference on Communication Networks and Services Research, Fredericton, NB, Canada, s. 305-314, DOI: 10.1109/DNSR.2004.1344743.

[7] Yuanyuan, Z., Xiaohua, J., Yanxiang, H. 2006. Energy Efficient Distributed Connected Dominating Sets Construction in Wireless Sensor Networks. IWCMC, s. 797-802, July, DOI: 10.1145/1143549.1143709

[8] Alahakoon, T., Tripathi, R., Kourtellis, N., Simha, R., Lamnitchi, A. 2011. K-path centrality: a new centrality measure in social networks. SNS '11: Proceedings of the 4th Workshop on Social Network Systems, s. 1-6, April, DOI: 10.1145/1989656.1989657

[9] Ding Y., Yan E., Frazho A., Caverlee J. 2009. PageRank for ranking authors in co-citation networks", Journal of the American Society for Information Science and Technology Volume60, Issue11 Pages 2229-2243 November, DOI: 10.1002/asi.21171

[10] Jagadishwari, V. and Chakrabarty, S. 2020. Link Prediction using Influencer nodes of a Social Network. 2020 Second International Conference on Inventive Research in Computing Applications (ICIRCA), Coimbatore, India, s. 927-930, DOI: 10.1109/ICIRCA48905.2020.9183315.

[11] Agryzkov, T., Tortosa, L., Vicent, JF., Wilson, R. 2019. A centrality measure for urban networks based on the eigenvector centrality concept. Environment and Planning B: Urban Analytics and City Science, 46(4) s. 668-689, DOI: $10.1177 / 2399808317724444$

[12] Öztemiz, F., KARCI, A. 2020. Akademik Yazarların Yayınları Arasındaki İlişskinin Sosyal Ağ Benzerlik Yöntemleri İle Tespit Edilmesi. Uludağ University Journal of The Faculty of Engineering, Cilt, 25. Sayl, 1. s. 591-608, DOI: 10.17482/uumfd.533476

[13] Needham, M., Hadler, A.E. 2019. Graph Algorithms: Practical Examples in Apache Spark and Neo4j. O'Reilly, May

[14] Pagerank Algorithm. 2020. https://neo4j.com/docs/graphalgorithms/current/algorithms/page-rank/, (Erişim Tarihi: 24.12.2020)

[15] Sariyüce, A.E., Kaya, K., Saule, E. And Çatalyürek, Ü.V. 2013. Incremental algorithms for closeness centrality. 2013 IEEE International Conference on Big Data, Silicon Valley, CA, s. 487-492, DOI: 10.1109/BigData.2013.6691611.

[16] Bonacich, P. 2007. Some unique properties of eigenvector centrality. Elsevier, Social Networks Cilt, 29. Sayı, 4. October, s. 555-564, DOI: 10.1016/j.socnet.2007.04.002

[17] Degree Centrality. https://neo4j.com/docs/graph- algorithms/current/labs-algorithms/degreecentrality/ (Erişim Tarihi: 24.12.2020

[18] Karci, A. 2020. New Algorithms for Minimum Dominating Set in Any Graphs. Anatolian Science, Cilt, 5. Sayı, 2. s. 62-70 